\title{
A UNIFIED APPROACH TO COPSON AND BEESACK TYPE INEQUALITIES ON TIME SCALES
}

\author{
S. H. Saker, R. R. Mahmoud And A. Peterson
}

\begin{abstract}
Using time scale calculus we will prove some new theorems that unify the proofs of the continuous and discrete Copson type inequalities and indeed extend the Copson type inequalities to general time scales. Our results prove that the inequalities are true when the exponent $k$ in Copson's inequality is negative and then prove that the approach that has been given by Bessack is also valid for the time scale cases.
\end{abstract}

Mathematics subject classification (2010): 26D10, 26D15, 34N05, 39A13.

Keywords and phrases: Copson inequalities, Beesack inequalities, time scales.

\section{REFERENCES}

[1] R. P. Agarwal, D. O’Regan And S. H. Saker, Dynamic Inequalities on Time Scales, Springer Heidelberg/New York/Dordrechet/London, 2014.

[2] R. P. Agarwal, D. O'Regan And S. H. SAKer, Hardy Type Inequalities on Time Scales, Springer International Publishing Switzerland, 2016.

[3] M. Anwar, R. Bibi, M. BOHNER AND J. PeČArić, Integral inequalities on time scales via the theory of isotonic linear functionals, Abstr. Appl. Anal. 2011 (2011), 1-16.

[4] P. R. BeEsAck, On some integral inequalities of E. T. Copson, General Inequalities 2, Birkhäuser Basel, 1980, pp. 151-159.

[5] M. Bohner And A. Peterson, Dynamic Equations on Time Scales: An Introduction with Applications, Birkhäuser, Boston, Mass, USA, (2001).

[6] M. Bohner, A. Peterson, Advances in Dynamic Equations on Time Scales, Birkhäuser, Boston, 2003.

[7] G. Chrystal, Algebra, an Elementary Textbook, v. 2, 7th ed., Chelsea reprint, New York, 1964.

[8] E. T. Copson, Note on series of positive terms, J. London Math. Soc. 3 (1928), 49-51.

[9] E. T. Copson, Some integral inequalities, Proc. Royal Soc. Edin.: Section A Math. 75 (1976), $157-$ 164.

[10] G. H. Hardy, J. E. Littlewood and G. Polya, Inequalities, 2nd ed., Cambridge Univ. Press, 1934.

[11] S. H. SAKER AND D. O'REgAn, Extensions of dynamic inequalities of Hardy's type on time scales, Math. Slovaca 65 (5) (2015), 993-1012.

[12] S. H SAKER And J. Graef, A new class of dynamic inequalities of Hardy's type on time scales, Dynam. Systems Appl. 23 (2014), 83-93.

[13] S. H. SAKER AND D. O'RegAn, Hardy and Littlewood inequalities on time scales, Bulletin of Malaysian Mathematical Science Society 39 2016), 527-543.

[14] S. H. SAKeR, D. O'Regan And R. P. Agarwal, Some dynamic inequalities of Hardy's type on time scales, Math. Ineq. Appl. 17 (2014), 1183-1199.

[15] S. H. Saker, D. O'Regan And R. P. Agarwal, Generalized Hardy, Copson, Leindler and Bennett inequalities on time scales, Math. Nachr. 287 (5-6) (2014), 686-698.

[16] S. H. Saker, D. O'Regan AND R. P. Agarwal, Dynamic inequalities of Hardy and Copson types on time scales, Analysis 34 (2014), 391-402.

[17] S. H. SAKer, D. O'Regan And R. P. Agarwal, Littlewood and Bennett inequalities on time scales, Mediterr. J. Math. (2014), 1-15. 
[18] S. H. SAKer, D. O'Regan And R. P. Agarwal, Converses of Copson's inequalities on time scales, Math. Ineq. Appl. 18 (2015), 241-254.

[19] S. H. Saker, R. R. Mahmoud And A. Peterson, Weighted Hardy-type inequalities on time scales with applications, Mediterranean Journal of Mathematics 13 (2016), 585-606.

[20] Fu-Hsiang Wong, Cheh-Chin Yeh, Shiueh-Ling Yu and Chen-Huang Hong, Young's inequality and related results on time scales, Appl. Math. Lett. 18 (2005), 983-988. 